\title{
Massive pleural effusion in an 18-year-old girl with Ewing sarcoma
}

\author{
Cengiz Özge MD, Mukadder Çalikoglu MD, Leyla Cinel MD, F Demir Apaydin MD, Eylem S Özgür MD
}

C Özge, M Çalikoglu, L Cinel, FD Apaydin, ES Özgür. Massive pleural effusion in an 18-year-old girl with Ewing sarcoma. Can Respir J 2004;11(5):363-365.

Ewing sarcoma is a bone tumour that commonly appears between ages five and 10 in the diaphysis of the long bones and predominantly presents with pain and swelling. The case of an 18-year-old girl who presented with back pain, cough, dyspnea, weakness and fever is described. Chest radiograph showed a homogenous density in the middle and inferior zones of the right hemithorax. Thoracic computed tomography revealed a diffuse pleural effusion and a $6.99 \mathrm{~cm} \times 4.45 \mathrm{~cm}$ solid mass composed of lobulated, small cystic lesions and calcifications in the right hemithorax.

Biochemical analysis of pleural fluid showed hemorrhagic effusion and exudate. A pleural needle biopsy demonstrated solid uniform tumour cells with narrowed cytoplasm, round nuclei and uncertain nucleoli. All of the tumour cell cytoplasms stained with CD99. The pathological examination supported Ewing sarcoma. Three-phase Tc-99m methylene diphosphonate scintigraphy of the whole body showed pathological tracer uptake in a broad area of the eighth costal bone and in smaller areas of the ninth and 10th costal bones. This case is reported because Ewing sarcoma is a rare cause of pleural effusion in clinical practice among younger adults.

Key Words: Adolescent; Ewing sarcoma; Pleural effusion

\section{Épanchement pleural massif chez une jeune femme de 18 ans souffrant d'un sarcome d'Ewing}

Le sarcome d'Ewing est une tumeur osseuse qui se manifeste souvent entre les âges de cinq et dix ans au niveau de la diaphyse des os longs et s'accompagne surtout de douleurs et d'œdème. Le cas présenté ici est celui d'une jeune femme de 18 ans souffrant de douleur au dos, de toux, de dyspnée, de faiblesse et de fièvre. Une radiographie pulmonaire a montré la présence d'une masse homogène à la zone médiane inférieure de l'hémithorax droit. La tomodensitométrie du thorax a révélé un épanchement pleural diffus et une masse solide de 6,99 sur $4,45 \mathrm{~cm}$, composée de petites lésions kystiques lobulées et de calcifications à l'hémithorax droit. Les analyses biochimiques du liquide pleural ont montré la présence d'un épanchement et d'un exsudat hémorragiques. Une biopsie pleurale à l'aiguille a pour sa part confirmé la présence de cellules tumorales uniformes avec cytoplasme rétréci, noyau rond et nucléoles imprécis. Le cytoplasme de toutes les cellules tumorales a exprimé le CD99. L'examen anatomopathologique a confirmé le diagnostic de sarcome d'Ewing. Une scintigraphie en trois phases par diphosphonate de méthylène marqué au Tc-99m de tout le corps a montré une absorption anormale du marqueur dans une vaste zone du huitième os costal et dans des zones de moindre envergure des neuvième et dixième os costaux. L'intérêt du présent cas réside dans le fait que le sarcome d'Ewing est une rare cause d'épanchement pleural dans la pratique clinique chez les jeunes adultes.
G wing sarcoma is the second most common malignant pri- mary bone tumour in pediatric patients $(1,2)$. It occurs more frequently in boys than girls and has been reported in three pairs of female siblings (3). The femur is the most frequent primary site for Ewing sarcoma and the pelvis is the second, accounting for approximately $20 \%$ to $25 \%$ and $20 \%$ of new cases, respectively (4). Tumours commonly develop in the metadiaphyseal parts of the long bones. Upper extremity sites, especially the humerus, comprise another $12 \%$ to $16 \%$ of new diagnoses, and the remainder of Ewing sarcomas originate from the vertebrae, ribs, clavicle, mandible and skull (3). The clinical presentation of patients with Ewing sarcoma is similar to that of patients with osteomyelitis (5). Ewing sarcoma of the chest is not rare, but having a pleural effusion is unusual. In the present report, a girl diagnosed with Ewing sarcoma as an uncommon cause of pleural effusion in clinical practice is described.

\section{CASE PRESENTATION}

An 18-year-old girl was referred with back pain for three months, cough, dyspnea and weakness for 10 days, and fever for three days. Her medical history had no relevant data. Family history was significant only for asthma in her mother. Physical examination revealed diminished breath sounds in the middle and inferior posterior right hemithorax, and dullness to percussion over the corresponding areas. The physical examination was otherwise unremarkable. Laboratory examination revealed moderate anemia (hemoglobin $85 \mathrm{~g} / \mathrm{L}$, hematocrit level $25 \%$ ) and a high erythrocyte sedimentation rate of $58 \mathrm{~mm} / \mathrm{h}$. Other abnormal laboratory values were: white blood

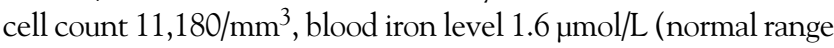
$8.77 \mu \mathrm{mol} / \mathrm{L}$ to $27.02 \mu \mathrm{mol} / \mathrm{L}$ ) and blood iron binding capacity $43.73 \mu \mathrm{mol} / \mathrm{L}$ (normal range $44.75 \mu \mathrm{mol} / \mathrm{L}$ to $76.07 \mu \mathrm{mol} / \mathrm{L}$ ). An erect frontal chest radiograph demonstrated a homogeneous density in the middle and inferior right hemithorax (Figure 1). 


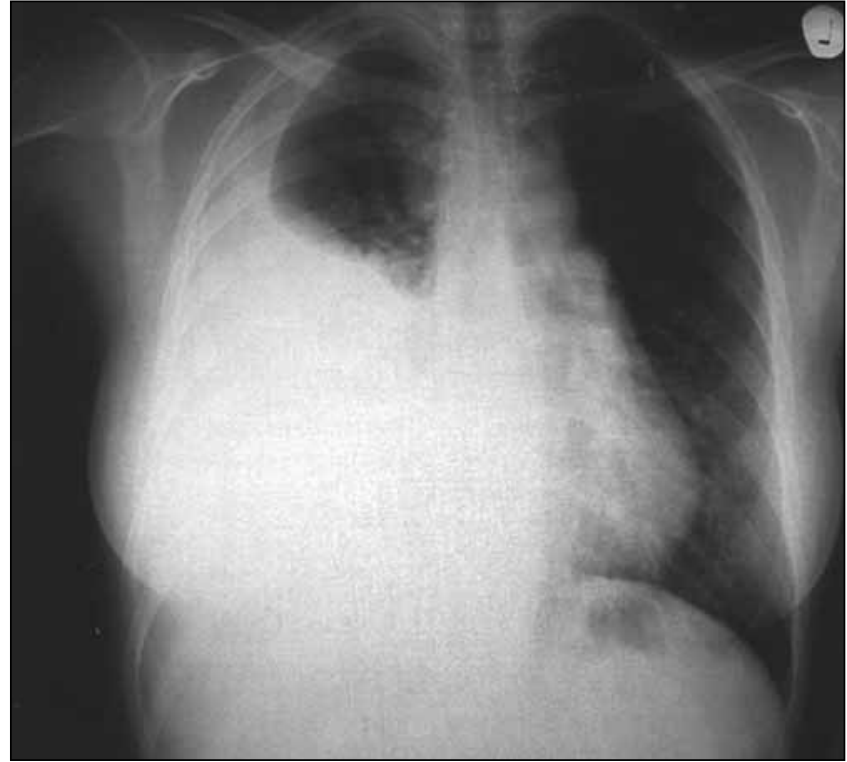

Figure 1) The chest radiograph shows homogenous density on middle and inferior zones of the right hemithorax

There was blunting of the right costophrenic angle, displacement of the cardiac shadow and opacification to the level of the second rib. This was in keeping with a large right-sided pleural effusion. Thoracic computed tomography examination revealed diffuse right-sided pleural effusion, a solid mass composed of lobulated, small cystic lesions, and calcifications in the right hemithorax (diameter of $6.99 \mathrm{~cm} \times 4.45 \mathrm{~cm}$ ) (Figure 2). In addition, there were erosive changes in the adjacent ribs and atelectasis in the right lung. Spine roadiographs did not show any pathological changes. Biochemical analysis of pleural fluid indicated an exudate (Table 1). The cytology of pleural fluid demonstrated abundant red blood cells, mesothelial cells and histiocytes. No malignant cells were observed. Pleural biopsy, with an Abrahams needle, demonstrated a solid uniform tumour, with the cells having narrowed cytoplasms, round nuclei and uncertain nucleoli. Necrosis or mitosis was not determined and rosette formation was not observed. The tumour cell cytoplasm stained uniformly with CD99, which is a MIC2 product (a specific surface membrane protein highly sensitive but not necessarily specific for Ewing sarcoma). The tumour tissue did not stain with keratine (CK 7), which is highly positive for synovial sarcoma. After the two procedures described above and other immunohistochemical procedures, the patient was diagnosed with Ewing sarcoma. Three-phase Tc-99m methylene diphosphonate scintigraphy of the whole body showed pathological tracer uptake in a broad area of the right eighth costal bone and in smaller areas of the ninth and 10th costal bones.

\section{DISCUSSION}

Localized pain or local swelling is typically the first symptom reported by pediatric patients with bone tumours. Fever is present in $28 \%$ of patients with Ewing sarcoma at the time of diagnosis (3). Metastases are present in approximately $26 \%$ of patients at initial diagnosis. The most frequent sites of metastases are the lungs and other bones. Multiple pulmonary metastases

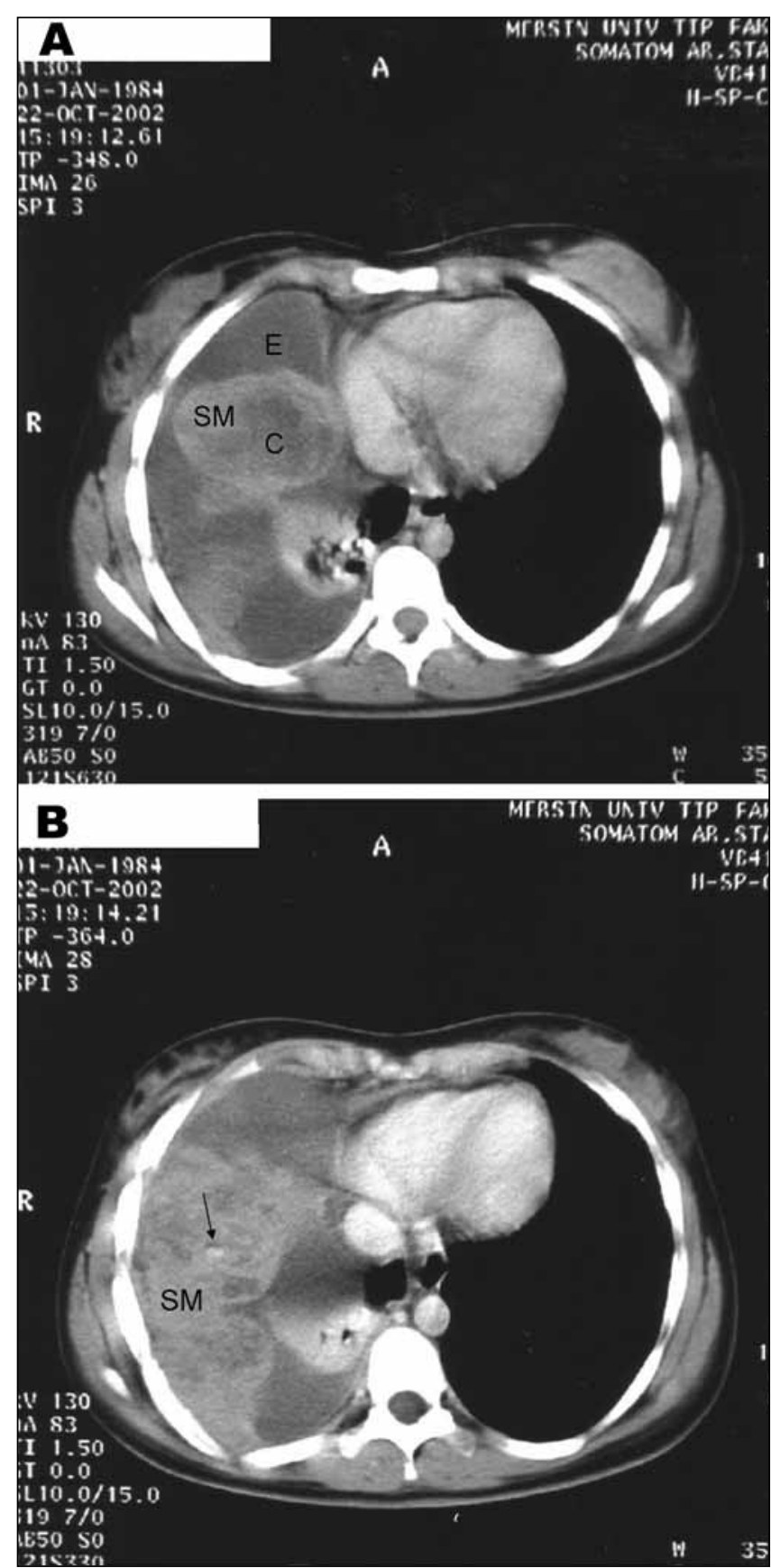

Figure 2) Thorax computed tomography shows diffuse pleural effusion and a solid mass composed of lobulated and small cystic lesions in the right hemithorax. C Cystic lesion; E Effusion; SM Solid mass. Arrow indicates calcification

may produce respiratory insufficiency, or paraplegia may develop secondary to a vertebral body metastasis $(6,7)$.

Massive pleural effusion is an unusual finding in young persons. Because of the high prevalence of tuberculosis in Turkey, most of the pleural effusions in the younger age groups are related to tuberculosis. Generally, hemorrhagic effusion or exudates are diagnosed as tuberculosis without a histopathological examination. Thoracentesis, and radiological and histopathological examinations are usually required to distinguish the etiology (8). In the present patient, a tumour of the ribs with 
TABLE 1

The results of chemical analysis of synchronous blood and pleural fluid

\begin{tabular}{lcc}
\hline Parameters & Blood & Pleural fluid \\
\hline LDH $(\mathrm{U} / \mathrm{L})$ & 218 & 450 \\
Total protein $(\mathrm{g} / \mathrm{L})$ & 76 & 75 \\
Albumin $(\mathrm{g} / \mathrm{L})$ & 38 & 31 \\
Glucose $(\mu \mathrm{mol} / \mathrm{L})$ & 5.55 & 4.66 \\
\hline
\end{tabular}

LDH Lactate dehydrogenase

involvement of soft tissues could have produced the pleural effusion. In our opinion, it is more likely that hemorrhagic effusion was secondary to diffuse pleural metastasis because the specimens from pleural surface and the solid tumour suggested the findings of Ewing sarcoma.

It is known that metastatic disease, tumour size (greater than $8 \mathrm{~mm}$ in diameter) and high serum lactate dehydrogenase levels are poor prognostic factors for Ewing sarcoma. On the other hand, an indicator of prognosis is a radiographical and histological response to inital treatment. According to the literature, after the six-drug regimen treatment of the present patient, the expected five-year, event-free survival would be $68 \%(9)$.

A case reported by Wolf et al (10) had similar characteristics to the present patient, except for the size of the tumour and pain localization. As Ewing sarcoma is a bone tumour of childhood (commonly develops between the ages of five and 10), our patient was older than usual, as was the case reported by Wolf et al (10). A massive pleural effusion with dyspnea as the first sign of Ewing sarcoma is the second important peculiarity of the present case.

\section{REFERENCES}

1. Ries LAG, Smith MA, Gurney JG, et al, eds. Cancer Incidence and Survival among Children and Adolescents: United States SEER Program 1975-1995, National Cancer Institute, SEER Program. NIH Pub No 99 4649. Bethesda, Maryland: National Cancer Institute, 1999.

2. Rosito P, Mancini AF, Rondelli R, et al. Italian cooperative study for the treatment of children and young adults with localized Ewing sarcoma of bone. Cancer 1999;86:421-8.

3. Green DM. Diagnosis and Management of Solid Tumors in Infants and Children. Boston: Martinus Nijhoff, 1985.

4. Grier HE. The Ewing family of tumors. Ewing's sarcoma and primitive neuroectodermal tumors. Pediatr Clin North Am 1997;44:991-1004.

5. Durbin M, Randall RL, James M, Sudilovsky D, Zoger S. Ewing's sarcoma masquerading as osteomyelitis. Clin Orthop 1998;357:176-85.

6. Glaubiger DL, Makuch R, Schwarz J, Levine AS, Johnson RE. Determination of prognostic factors and their influence on therapeutic results in patients with Ewing's sarcoma. Cancer 1980;45:2213-9.

7. Rosen G, Caparros B, Nirenberg A, et al. Ewing's sarcoma: Ten-year experience with adjuvant chemotherapy. Cancer 1981;47:2204-13.

8. Loddenkemper R. Pleural effusion. In: Albert R, Spiro S, Jett J, eds. Comprehensive Respiratory Medicine. Basildon, United Kingdom: Mosby, 1999.

9. Grier H, Krailo M, Tarbell N, et al. Adding ifosfamide and etoposide to vincristine, cyclophosphamide, adriamycin and actinomycin improves outcome in non-metastatic Ewing's and PNET: Update of CGG/POG study. Med Pediatr Oncol 1996;27:259. (Abst)

10. Wolf G, Aigner RM, Schwarz T. Massive pleural effusion with dyspnea in a 17-year-old boy as the first sign of Ewing sarcoma. J Pediatr Hematol Oncol 2002;24:420. 


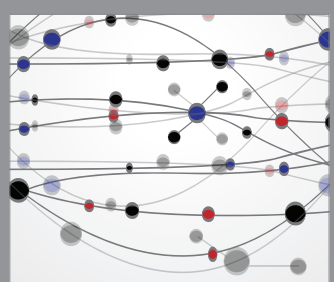

The Scientific World Journal
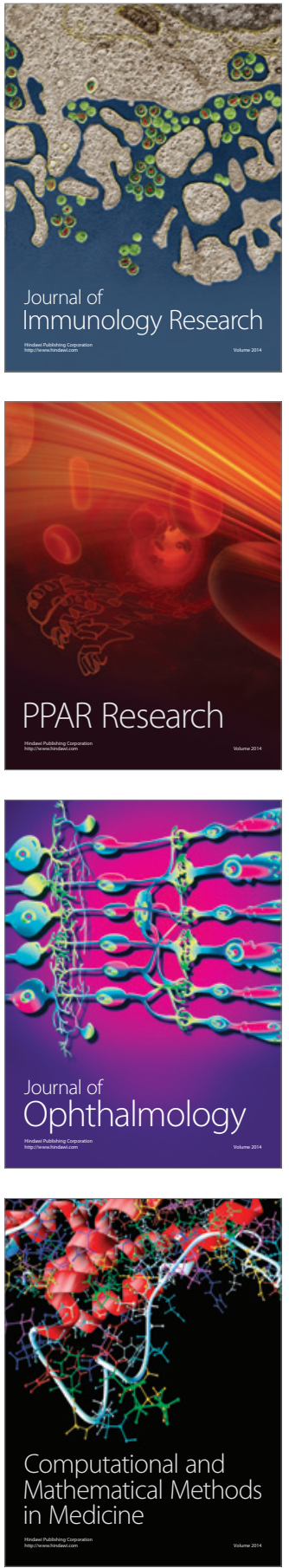

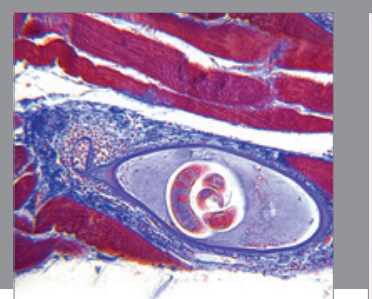

Gastroenterology Research and Practice

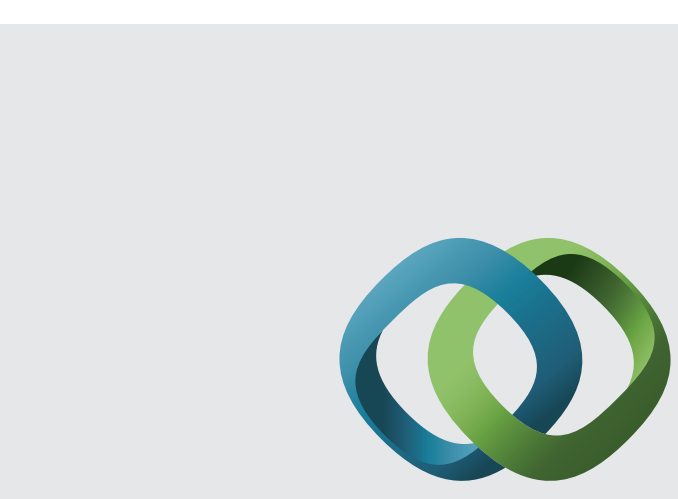

\section{Hindawi}

Submit your manuscripts at

http://www.hindawi.com
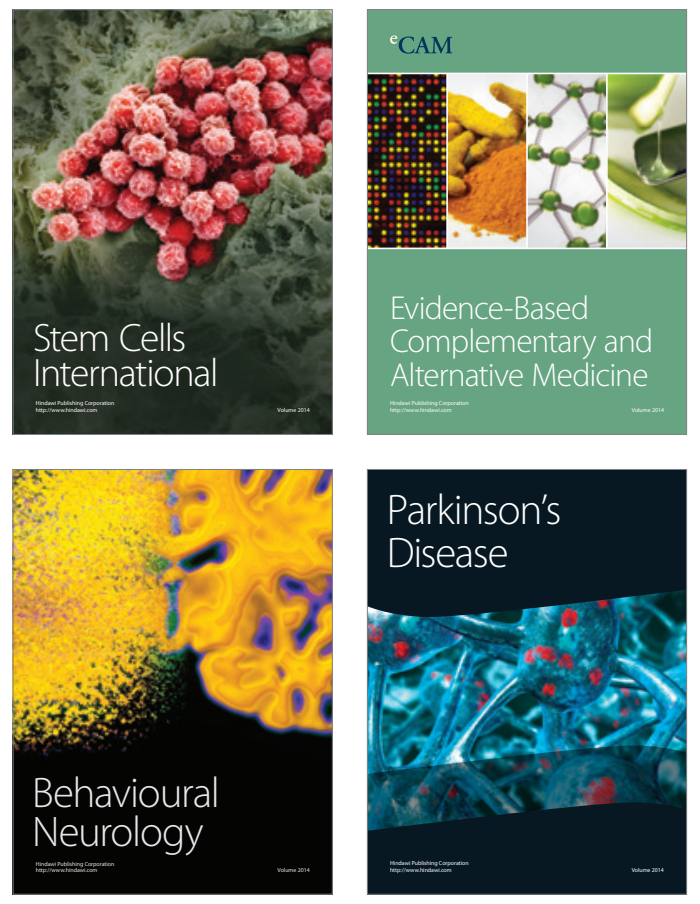
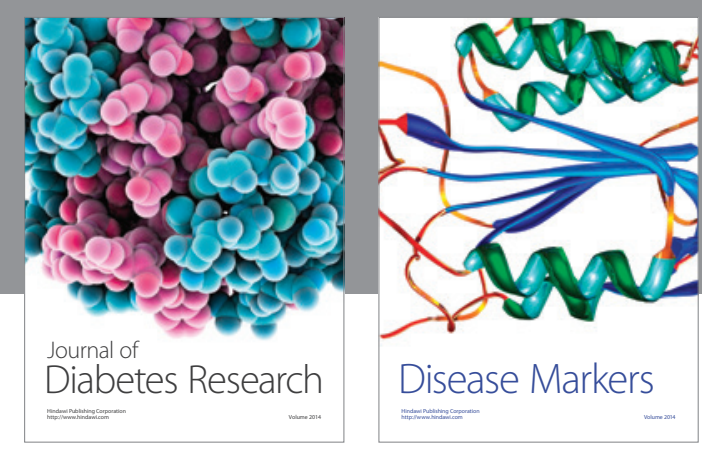

Disease Markers
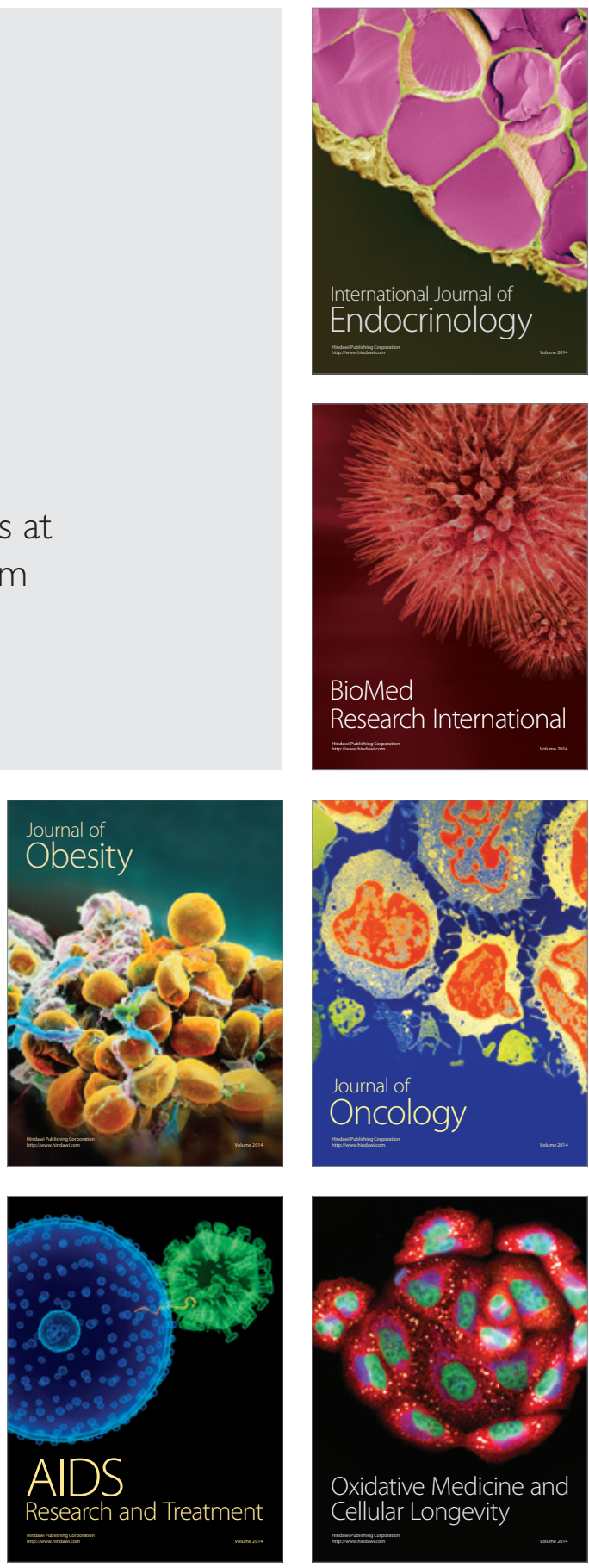